\title{
Early Childhood Environmental Education (ECEE): Issues and Curriculum Implications in the Nigerian Context
}

\author{
Amadi Ugochukwu P.N \\ Amadi Felicia .N.C \\ Federal College of Education (Technical), \\ Umunze-Anambra State, Nigeria
}

\section{Doi:10.5901/ajis.2013.v2n12p123}

\begin{abstract}
The paper titled Early Childhood Environmental Education (ECEE) was designed as an appraisal study with its main objective as determining strategies for integrating ECEE into Early Childhood Care Education curriculum. Review was made of conceptual frame-works of early childhood, environment and environmental education. Also reviewed were earlier studies and scholarly opinions on the subject, based on which strategies were recommended in a way that would engage formalized processes of the curriculum in its dispensation. Recommendations made included that environmental education be introduced into the Early Childhood care Education (ECCE) curriculum, parents and adult members of the society are engaged as instructors. Recommend curriculum strategies included: use of games and simulation on environmental thematic issues, creations of nature's corner in schools, organization of fun-fares, exhibitions fieldtrips and excursions to historical natural resources, use of nature and environment-based films, home-videos, textual materials and pictorials to convey environmental education messages to the young kids. The study was concluded by emphasizing the need to engage young kids in environmental issues that could capitalize their young impressionable minds as to shaping their attitudes towards nature and its resource base as well as their use and conservation as to ensuring their profitable and sustainable management.
\end{abstract}

\section{Introduction}

Early Childhood refers to preschool years, typically occupied by children between 2-5 years of age; it is a stage of development which spans from pre-nursery to nursery level of education, a time during which child-toddlers and preschoolers begin their exploratory activities. According to Nnachi (2004), it covers the period of toddlerhood and the time of entering primary school. In the words of White and Waltz (1973) early childhood describes the period during which young children engage seriously in play activities as their major work and spend a deal of time exploring, inventing, experimenting and learning about events as well as mastering their world. With their play behaviour they struggle to adapt to the environment by developing various activities.

Being that the education of a child starts from infancy, all societies train their children on socialization and general behaviour right from birth, thereby helping them learn about themselves, their personal boundaries; learn about the world around them, learn about different objects and their qualities, learn about relationships, the way to respond to others etc. According to Piaget's cognitive development theory, early childhood falls within the pre-operational stage, a time when children learn the use of language, mental imagery as well as categories and use of symbols to represent what they learn. The development of children's social mental, physical and emotional abilities begins at early childhood, it therefore becomes necessary that parents and older adults must be fully involved in the education of the child which can be done by sending them on errands, 
telling them short and interesting stories bordering on morals, discipline and sense of industry; teach them to be obedient and to have respect for elders. Through these ways children will acquire behaviour patterns, abilities and skills needed for successful survival in the society.

\section{Early Childhood Education}

Early childhood education is a programme of instruction organized for children from birth to preschool age to make them thrive (Akinola, 2004). Preschool years are crucial years during which the young child develops his social, mental, physical and emotional abilities with which he faces the challenges of primary education. It is a programme designed for children to give them a solid foundation of experience and to prepare them for entry into primary school. The achievement of these objectives to a reasonable extent lies on the efforts of preschool educators. This implies that the preschool educators and care-givers must provide a stimulating and interactive environment in which children would gain the freedom to explore their environment through exploratory play activities. No wonder Akinola (2004) opines that children at this stage need to be nurtured because they have a number of 'survival needs' Therefore the responsibilities of preschool educators border on the following cardinal areas namely; provision of care, love and protection from all injuries and attacks of all kinds. In addition they need sound nutrition (balanced diet) to be healthy and to resist diseases; goods buildings, classrooms, library, laboratories, instructional hardware and good play grounds for physical activities. All these are measures for equipping and preparing them for the primary and indeed other levels of education. 'From the foregoing, it becomes necessary that the teaching and learning of environmental education will be better if initiated at this period so as to prepare and help them develop positive attitudes towards nature since early years are learning years (Nnachi, 2004).

\section{Environment}

Environment may be explained as the social world or a geographical area which has the potentials of influencing the behaviours, perception, attitude and psychological disposition of individuals that are associated with it. It can influence the behaviour of children positively or negatively and thereby determine their actions. Considering the influence of environment on human development, Nnachi, (2004) asserted that for human beings to become what they are at any given time depends on the social environment they find themselves. He further stated that environment as a world can motivate or suppress the manifestation or development of the potentials of an individual. This is on the grounds that environment provides us with air, water and food and accounts for material provisions that assist the individual children in day-to-day living. It also provides us with the open space where playful activities take place. He added that the experiences a person gains in his environment influences his behavior and development. Therefore, for children to be educated environmentally, it becomes necessary to make the learning environment stimulating, conducive and interactive in order to promote learning and help children to develop positive attitude towards nature.

\section{Early Childhood Environmental Education}

Early Childhood Environmental Education (ECEE) in absolute sense may not necessarily be the formalized type where a teacher interacts with learners through the medium of, or instrumentality of the lesson plans. In the context of this writing ECEE is used to generally represent with the exposure of children to the out doors. It further indicates how the adult members of the society help to create members of the society help to create environmental awareness in the young children so as to enable them to appreciate the awesomeness of nature. It demands that parents, educators and care-givers should guide their children and wards to think and relate positively to 
nature (Robertson, 2008).

Environmental Education at the early stages of life should be more responsive to the developmental needs and tasks characteristic of that stage of life. This is only possible when it is focused more on play, discovery and exploration, rather than formal instruction (Armitage, 2007, Boyle, $2006 \&$ White, 2006).

According to Wilson (1996) ECCE captures that critical time in the life of children when they do not only exist in their most impressionable states of being but, are also powerful agents of change. Corroborating the above view Louv (2007) argues that the early childhood period is when most people develop their phobias of and their affections for the natural world around. These arguments go to support the claim for a connection between a child's early life experience and the development of attitudes as well as the way of appreciating and understanding the world around us.

The precocious nature of the early childhood kid demands that enough opportunity be provided for hands-on experiences that will enable them to construct their knowledge base or foundation (Paget, 1947 \& Bandura, 1997). By this approach ECEE children are guided to develop positive and beneficial attitudinal dispositions to nature and the world around (Robertson, 2008). This could be implied in the words of Wilson (2006) when he argued that rural-bound children who consistently experience nature tend to develop more positive attitudes towards it than their urbanbased peers. However, positive relationship between children and nature can be enhanced by reinforcing nature-based experiences of their early life (Hungerford \& Volk, 1990).

Stressing the critical need to expose children early enough to environmental education Rachel Carson (1956) in her work titled "Help your Child to Wonder" observed as follows:

For the child, it is not half so important to know as to feed. If facts are the seeds that later produce knowledge and wisdom, then the emotions and the impressions of the senses are the fertile soil in which the seeds must grow. It is more important to pave the way for a child to want to know than to put him on a diet of facts that he is not ready to assimilate.

The imperative of Carson's message is the need to create a sense of wonder and inquisition in the young impressionable minds of the kid-learners, helping them to appreciate early in life, the value of childhood experiences in nature. Children need therefore to be connected with nature as early as it is possible in their life-space, through both formal and informal designs.

Scholars of repute have confirmed that development of creativity, power of imagination and inquisition in people that manifest in later stages of life has a direct bearing with early childhood experiences with nature. This claim as supported by Devall, (1984), Sebba (1991) and way and manner such people interact with the natural world. Childhood encounters with places of nature such as caves, forests, rivers, etc in their exploratory activities have positive correlation with their later life attitudes towards such nature's resources as adults. It is therefore imperative that nature be "cultivated" in the minds of children as well as in the physical areas not naturally endowed for the benefits of children. Such areas include 'green' development (integrating green plants in environmental projects), walks ways, children's amusement parks, play grounds, lawns. that are well tended, potting of plants (in door/out door species) and use of hydroponics could produce amazing environmental experiences for young children, who should be encouraged to regularly visit such nature's corners and engage in natural activities.

\section{Issues in Early Childhood Environmental Education (ECEE) Curriculum}

Critical issues on ECEE as addressed in this paper are summarized as follows:

i. Making ECEE mainstream of Early Childhood Care Education programme.

ii. Sustaining ECEE in the paradigm of curriculum and schooling.

iii. Connecting young children with the natural world. 
iv. Creating outdoor play environments for children to be embellished with natural ornamental plant species.

v. Introducing children to Environmental Education through everyday exposure to experiences they can understand appreciate and relish.

vi. Connecting kids to nature family activities: Activities should be constructed to support instruction and learning in environmental science, biology, gardening and human geography. Such activities should be designed to have a little fun and excitement for the kids. On daily basis, children should be engaged in thinking about the environment as a 'living entity', and the future as well as the relative importance and utility of sustainable and culturally acceptable environmental practices.

vii. Early Childhood Care Education (ECEE) curriculum should emphasize engaging children in the following environments sustainability areas of prime importance;

- gardening and floriculture

- compositing and waste management

- energy conservation and renewal

- green play experiences

- recycling and reused of bio non degradable resources

- sustainable food practices.

\section{Recommended Curriculum for Effective Early Childhood Environmental Education}

Sustainable and effective ECEE can be achieved through:

1. Games designed to assist children to learn from nature in very insightful and joyful ways.

2. Bringing outdoors into the classroom by the use of play-toys made from natural materials such as clay, wood and other crafted works, keeping of potted plants (especially flowering species), live animals in cages and aquaria for aquatic species.

3. Simulating nature and important natural phenomena bordering on environment such as birds, wildlife, rivers, lightening, erosion, night-sky, environmental pollution and climate change.

4. Telling of stores and folk-tales with nature and environmental significance.

5. Organizing contests, fun fairs and exhibitions with thematic emphasis on environment and nature.

6. Organizing of field trips and excursion to natural landscapes and historic sites.

7. Nature and environment-based films, games, home videos, novels and pictorials.

8. Establishing agency that will form time to time organize competition for children with the intension of working across generations sharing their interactions and experiences..

9. Establishing nature nursery school centres far preschoolers where the teaching of environmental education will be accessible to children from diverse backgrounds.

10. Regular seminars, workshops and conferences for ECEE teachers so as to keep abreast of currency in environmental education with special reference to environmental degradation management, pollution, pollutants, climate change and effects of human activities.

\section{Conclusion}

This paper has attempted to X-ray the nature, scope and processes of Early Childhood Environmental Education. It concluded by making some recommendations on strategies with curriculum implication as a way of guaranteeing the realization of EE objectives.

\section{References}

Akinola, B.M.A (2004): The Place of Pre-Primary Education in Nigerian's National Policy On Education 
J ournal of Educational Studies and Research (NJESR) 2 (25).

Armitage K.C (2007): The Child Is Born A Naturalist: Nature Study, Wood Craft Indian, And The Theory Of Recapitulation. J ournal of The Gilded Age and Progressive Era 6 (1).

Amadi, U.P.N (2012): Environmental Education in Agriculture. Foundation Studies in Agriculture (Amadi U.P.N \& Orikpe E.A (Eds): Umunze, Annyco Printers \& Publishers.

Amadi F.N.C (2012): Early Childhood Care Education in Nigeria. Challenges Among Private Care Providers. Doctoral Seminar Paper Abia State University , Uturu.

Bandura, A (1977): Social Learning Theory, Upper Saddle River, New Jersey, Prentice Hall.

Boyle, L (2006): Environmental Experiences in Child Care. Putting Children First 1(19).

Denvall, W (1984): A Sense of Earth Wisdom. J ournal of Environmental Education 16 (2).

Hungerford, H.R \& Volk, T.L (1990): Changing Learner Behavior through Environmental Education J ournal of Environmental Education 21 (3).

Louv R (2005): Last Child in the Woods: Chapel Hill, North Carolina: Algonquin Books of Chapel Hill.

Louv R (2007): Leave No Child Inside; Orion Magazine (March/April Issue).

Nnachi, R.O (2004): Introduction to Psychology in Education ( $2^{\text {nd }}$ Edition). Owerri Barloz Publishers Inc.

Piaget, J (1947): The Psychology of Intelligence. London: Psychology Press.

Roberstson J.S (2008): Forming Preschoolers' Environmental Attitude: Lasting Effects of Early Childhood Environmental Education Thesis.

Sebba R. (1991): The Landscapes of Childhood: The Reflection of Childhood's Environment In Adult Memories and In Children's Attitudes. Environment and Behaviour. 23(4).

White, R.L and Watts, K.C (1973): Experience and Environment. New J ersey, Prentice Hall.

White, R (2006) Young Children's Relationship with Nature: Its Importance to Children's Development and the Earth's Future. Taproot 16(2).

Wilson, R.A (1996): The Development of Ecological Self. Early Childhood Environmental Education J ournal $24(2)$ 
